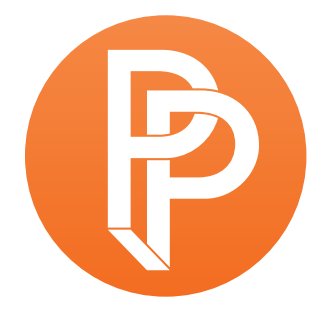

PERFORMANCE

PHILOSOPHY

\title{
ROOTED HAUNTOLOGY LAB: ATTEMPTS AT VEGETAL CURATION
}

\section{INGRID VRANKEN}

We live in extractivist times. The Western way of living is based on taking and consuming without providing the elements for regeneration. Alberto Acosta gives as the most comprehensible definition of extractivism, "those activities which remove large quantities of natural resources that are not processed (or processed only to a limited degree), especially for export. Extractivism is not limited to minerals or oil. Extractivism is also present in farming, forestry and even fishing;" "a mechanism of colonial and neocolonial plunder and appropriation" (2013,62-63). We are burning our way through fossil fuels, primary resources and humans. We are taking from the earth at a speed which does not allow for regeneration, with the well-known dramatic destructive consequences. As a curator I realize that the Western (performing) arts world is no exception to this way of functioning. Artists are making work that critiques neo-liberal capitalism, and institutions organise festivals on topics such as climate change, however often the politics, issues and utopias that are brought to the stage are not reflected in the conditions and context in which work is created and presented. Artists are working in increasingly precarious circumstances. Many of them feel that the financial and other stresses they are under are in contrast with the perceived wealth and stability of arts institutions, and these institutions are not sufficiently redistributing their resources towards a diverse group of artists. This growing gap in the arts field risks to leave the field divided and weak. In the past years, multiple stories of power abuse have come to light partly thanks to the power of the \#MeToo movement, while the rates of burn-out within the art field keep increasing (De Meyer, 2017). On an ecological level, there is still very little awareness of the materials we use to produce our art, let alone a mature, in-depth discussion about the travel habits of our field. Thanks to the efforts of activists such as Fossil Free Culture, we are aware of the 
continuous financing of the art world by fossil fuel companies. The art world participates in the neoliberal practices of power abuse where people are being squeezed for their time and talents and thrown aside when exhausted, and in the use of natural resources without taking responsibility for the renewal of the ecosystems and societies they are taken from. There is a gap between the politics performed on stage and those lived backstage, between strong ethical choices made in private lives and the lack thereof in professional lives.

Starting from the conviction that the context in which artistic work is created is defining the work itself, I began to co-work with plants because of their different relation to presence/absence, visibility, time and generosity, in order to shape a curatorial practice that tries to resist the (self)exploitation of human and other-than-human resources. For this I needed to reconsider longestablished hierarchies and practices through shaping relations and ethics differently. I turned towards plants and ghosts as my teachers and allies who could point me towards strategies of being-with, generosity and sympoiesis (Dempster 1995). Rooted Hauntology Lab, as an artisticcuratorial project, is both the result and ongoing practical playground for this experimentation. The Lab was created two years ago within the context of my Master's Studies at DAStheater in Amsterdam. The lab has currently produced two lecture performances in collaboration with different artists, workshops, writings, artist residencies and a séance as a public gathering. It is an ongoing project that, up until now, has been realized with minimal financial, material and institutional means. It is undeniable that the context of the Master's studies has strongly shaped the first iterations of the Lab, and as it will travel through collaborations with other organisations and institutions in the coming time, new insights will be gained and the practices of the lab will be further developed. This paper describes these personal attempts so far.

\section{Rooting}

I am fascinated by plants, these beings who have developed such diverse and successful ways of being on this planet, so different from humans. Plants are highly collaborative and generous, as research showed, both within their own species as well as through a multitude of collaborations with fungi, insects, and mammals (among others, see Simard 2013; Wohlleben 2015; Bieman and Tavarres 2014). How could I learn from plants? How could the knowledge of plants inform our workday, our collaborations, our organizations? What general plant strategies can we notice, and which specific plants can we call to our aid and provide with space to act? After some early explorations that involved taking audiences into the forest, it became clear that I needed to find a different strategy to engage with plants in a way that could truly challenge the automatic, anthropocentric and romanticised associations around working with plants. I was searching for a stronger uncanny and uncomfortable element, which could create a more powerful gesture towards the artistic institutional context and could also speak to the extractivist practices the project was trying to address. This brought me to the decision to work with potted plants, and mainly exotic species that are currently considered "trendy." Plants in pots appeared to me as a perfect illustration of the absurd perversion of our current societal and cultural state. The potted plant is to many a mere consumer object, in the worst case they are considered disposable. The 
aesthetics of these plants are seen through the lens of fashion and trends. Witness of this are the countless monsteras and money trees that can be found on Instagram as well as in the garden centres. Their individual physical characteristics get homogenized and they are marketed on the bases of properties that are deemed "good" (read: a commodity) for the human consumer, such as their air-purifying qualities, or the fact that some of them do not need to be watered that often.

These exotic species are often connected to colonial pasts (Schiebinger 2007) and practices of selection and genetic modification. But the haunting that envelops the potted plant becomes even more apparent when we think of how plants sustain themselves and their relations. Research has shown that plants have intricate and lively systems of exchange and communication that for a large part happen through the root-system and mycorrhizal networks (among others, see Simard 2013, 2018). Through this fine network of fungal threads in the soil that intertwines with the roots of trees and plants, they exchange nutrients and information. In the pot, the plant is completely dependent on the care of their human "owner." They cannot grow in search of water and minerals as they would do outside of pots. In the pot, the plants are completely cut-off from their possibilities of communication, community, interaction, and support. The plants become prisoners. They are stripped of the possibility to care for themselves and each other. By acquiring and working with plants in pots I am obliged to acknowledge this perverse dynamic between us from the start. There is no innocence in our co-working. I am complicit in their mis/displacement and will have to find ways to deal with the innate oppressive nature of our relationship.

\section{A recipe for infiltration by vegetal ghosts / Step 1}

Rooted Hauntology Lab invites you to execute a recipe, developed in collaboration with Sepideh Ardalani, as an attempt to contaminate the institutional time of schedules and fiveyear funding plans, the human time, the time of labour, the unnoticed time. This is a recipe for a layered, more-than-human time. It will help us learn from plant-allies and allow us to dream, giving space to ghosts and non-extractivist future visions. Depending on the dosage the recipe can be a medicine, a poison, a placebo.

For our recipe we invoke 4 particular co-workers, or ghosts as you wish: Evening civil twilight, Stinging Nettle, Mugworth and Daisy. To execute the recipe gather the needed co-workers and a small paper or textile bag. The vegetal ghosts can be freshly picked or dried. They can be foraged or store bought.

We invoke evening civil twilight!

This is the instant when the geometric centre of the Sun is 6 degrees below the horizon. It occurs in the morning and in the evening. Evening civil twilight is a layered time: the 'civil' in civil twilight points at the light as experienced in the "civilized world," the world of "civilians" or those whose voices can be heard, those who can vote, those "who count." But twilight has many meanings. In German this translates to either "Dämmerung" or "Zwielicht." Zwielicht 
can also be used as an adjective to describe someone suspicious. If something "dämmers" you, you are at the threshold of understanding something on a whole new level. This also exists in English: "It dawns on me," and in Dutch, "het begint me te dagen." (Wenner 2019, n.p.)

We invoke civil twilight to bring the dawn of a new understanding of the civil including otherthan-human bodies.

We invoke civil twilight to leave behind the Eurocentric, anthropocentric and racist implications of the term civil.

We invoke this potent time of the evening to bring us new understandings of our times.

\section{Ghosts}

Thinking plants as ghosts emerged first as a way to counteract the romanticising of plants, but soon proved to be an unmissable tool to rethink relationships both with the human and otherthan-human (Hallowell 1960). Hauntology gives us some handles to understand how seeming absences and invisibilities influence our experiences and understandings. I got inspired by Derrida (1994) who coined Hauntology as a term which points at the idea that everything that exists is also constructed through what it is not. Everything is defined by absence. To haunt is to be present through absence. Mark Fisher in his turn pointed me towards the importance of time when thinking about ghosts, proposing that hauntology points at a crack in time: the past and future are continuously influencing, haunting the present $(2014,18)$. Inspired by these readings I started to consider the relation between the human and the vegetal as ghostly in a variety of ways. Being amongst the plants, the diversity of possible temporal experiences becomes obvious. A plant sometimes takes hours or days to react to an external impulse. A tree grows throughout numerous human generations. I wonder if a cutting from a plant can be thought of as a new plant or as a continuation of the original plant, a moment where linear time branches out. Plants consist of dead parts, living parts and dying parts, often using their own decaying body as nutrients and by doing so bridging the seeming divide between life and death.

Plants in pots are haunting us with the absence of their ecosystem. Their communication systems are present, but inaccessible to us without technological intervention. Their lively internal dynamics remain invisible and inaudible for our senses. Thinking plants as ghosts asks us to add an extra dimension to hauntology and the agency of the virtual (Fisher 2014, 18). We need to branch further outside of no longer and not yet, breaking time and space, opening it up to understand the agency of that which is "unseen" to the human eye (and therefore could be considered "virtual") because it is other-than-human. I am not proposing plants as ghosts in a metaphysical, let alone supernatural, way. I am proposing that plants are ghosts because of their material and physical expression and because of their very material relation to time, life and death. Simultaneously, they are mainly ghosts in the limited and limiting experience of humans, who seem to have developed a "plant blindness" (Wandersee and Schussler 2001) and in doing so have outcasted plants to the realms of invisibility. This understanding of plants as ghosts is not related to folkloric beliefs or shamanistic practices including plant-spirits. In the worst scenarios, this could be an appropriation 
and misinterpretation of various Indigenous cultural and medicinal practices. I would also want to stay away from any form of essentializing the plant, by suggesting it has a spirit which can be seen as its "core," its "essence" or most "pure expression of its Self." Thinking plants as ghosts allows me to create a broader and more experiential understanding of relationality and the various places plants take within relational frameworks. The figure of the ghost allows us to account for acts and agency that are visible or invisible, present past or future. In a haunted world, all relations matter and act.

Anna Tsing points at a similar potential of "seeing" ghosts, however more directed towards their power to counteract forgetting, in the introduction to The Arts of Living on a Damaged Planet:

\section{Ghosts point to our forgetting, showing us how living landscapes are imbued with earlier tracks and traces. [...] Ghosts remind us that we live in an impossible present - a time of rupture, a world haunted with the threat of extinction. Deep histories tumble in unruly graves that are bulldozed into gardens of Progress. (Tsing et al. $2017,1: 6)$}

In that sense, the ghosts of plants are diverse and multiple: from the stories they carry because they were gifted by loved ones, to the various complex histories they bring to light, or even to their most invisible gift of oxygen, which connects all that lives. Seeds, for example, are the ghosts of the many forms they could become, dependent on the conditions in which they will be planted. They are the ghost of the flower they once were part of, the ghost of the place they were harvested from, the ghost of the intercontinental travels in colonial pasts that brought their forefathers here, the ghosts of the extinct species that used to carry them across the land, the ghosts of the technological fertilizing methods that will multiply them in the future, the ghosts all of the conditions in which they will never grow. Through exploring plants as ghosts, I wanted to bring all our unseen relations into consciousness, hoping that this would make us able to respond to them and work with them towards other practices and futures, than those which are presented to us. A ghost as full potential and a tool for making change.

Step 2

We invoke the ghost Nettle, Netel, Ortie or Urtica dioica!

As common and abundant plant in Europe, it is often the first plant to appear on an abandoned plot. Their preference for polluted and nitrate rich soils makes them the ideal being to reseed the capitalist ruins of pollution and extraction and make space for new futures. Nettle metabolizes the pollution, which cannot be found back in the picked leaves. Its roots grow very deep and are rhizomatic. Nettles endure and persist. Clothes made from Nettles have traditionally been used to bury the dead. Their antibacterial and anti-fungal properties prevent quick decay of bodies. In that sense, Nettles are also archivers of the past. Their sting is a venom that heals. Nettle is widely used for culinary and medicinal purposes. They are known 
as a purifier of the bloodstream and reliever of fatigue, and they are said to help people who are too nice and have difficulties in setting their boundaries wisely.

We invoke Nettle to set our boundaries within the capitalist demands for ever more extraction and production. Both of natural and human resources.

We invoke Nettle to reseed the exhausted space of burn-out and create a new perspective on time.

Take Nettle in your hands, crush the leaves in between your fingers.

Now spit in your hands. Our spit, and the enzymes in it, will allow Nettle to slowly ferment, activating their properties.

Add the mixture of Nettle and spit to your bag.

\section{Being-with}

Occupying a studio with the haunted and misplaced potted plants I gathered as my co-workers, I figured that in order to learn from them I had to start off my search by committing to a practice of being-with.

\section{Being-with involves allowing yourself to be touched by the joys and sorrows of another. To be touched by external circumstances, or as the Dutch so eloquently say, to be 'ontroerd.' Thrown off-course by the sheer rawness of the moment, by your own inability to make things better, by our fragility, impermanence and mortality. (Kuzmanovic and Gaffney 2018, n.p.)}

I want to open myself up to be thrown off-course by my vegetal co-workers and to stick to the ambivalence of our collaboration and what might sprout from that. I start my days in the studio with observing and caring. I attune myself to their presence, to photosynthesis, to the processes that transform $\mathrm{CO}_{2}$ into oxygen, the slow sucking up of moisture by the roots, the drop of condensation rolling of the leaf. I increasingly do less and less. I slow down and try to observe details with full attention. An observation without judgement, without the desire to get something from the other, a radical noticing. Sometimes it feels as if I fold into the plant, my arms interlaced with their leaves as if I could slip through my own pores to feel the chlorophyll on their surface. They are starting to take over my thoughts. I focus on the silence that now, in between all of these plants, seems much denser. I look for ways to work with the plants: I put on music which is supposed to enhance their growth, I take pictures of details, move them around in the space according to my growing attention to their reactions to the light, I pluck away a dead leaf, or I speak to them. I am a West-European woman who is talking to plants, who expects them to answer her questions.

It is hard to collaborate with beings that seem so quiet to my limited human senses. I feel how loud and present I am and how I continuously try to control the situation through interpretation. Despite the fact that I talk a lot, I have very little to say. In my attempt to communicate, every observation 
becomes wildly important. A leaf that folds or falls, the speed at which water is being absorbed. By myself, I have no tools to adequately comprehend the state of the plants. Does something like happiness exist for them? Is this an ambition I can hold for them? I catch myself in these melancholic, romantic and anthropomorphic thoughts, betraying my own research. A friend sends me an e-mail with a poem by Wisława Szymborska titled "The silence of plants," which captures my reflections perfectly.

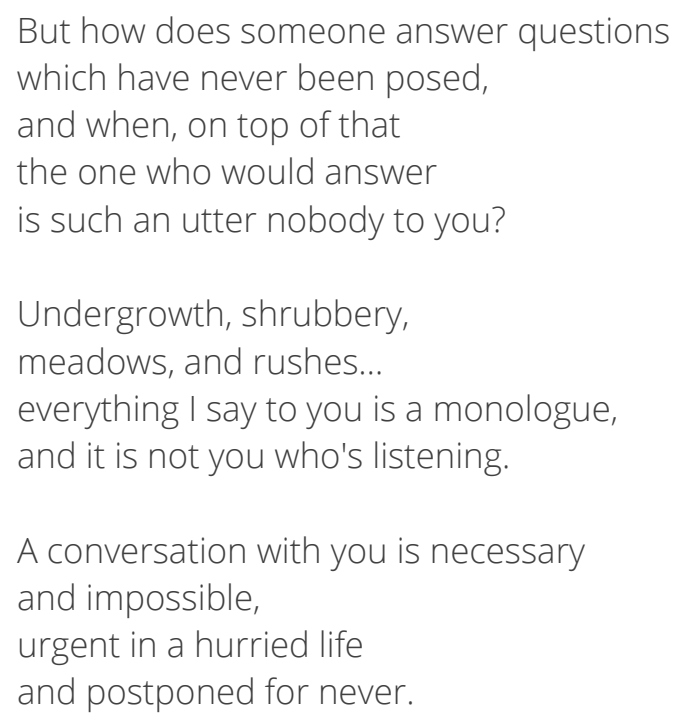

From Wisława Szymborska, 'The Silence of Plants' $(1999,269)$

The time together with my co-workers have made me overly attentive to the plants everywhere around me. Some majestic, others in a pitiful state. I develop the habit of watering dried-out plants wherever I go. I have the impression the plants are screaming at me from all sides. This has made me think how their seeming silence is an invitation to develop attitudes of listening. Listening is not passive, it is an action, engaged and committed. Listening requires patience, even if we don't fully understand right away what we are listening to and what for; it requires a suspension of one's own desires to dominate or push the other towards what they "should be" doing, thinking or saying. Listening is done with the whole body. Listening means "staying with the trouble" (Haraway 2016).

\section{Being-with other humans}

After almost a year of practicing co-working with plants on my own, the step was taken to broaden the practice of being-with to other humans. Three artists, Špela Petrič, Vinny Jones and Sepideh Ardalani were invited for a four-week residency within the buildings of DAS Graduate School in Amsterdam. In the selection of the artists, I focused on bringing different knowledges and disciplines around the table and mixing artists who already work with plants and artists who had never worked with plants before. Besides resonating with their artworks and the subjects they work with, I was mainly interested in how these artists were organizing their artistic processes with awareness for their productional context such as: how they work with collaborators, how they 
strategize and collaborate with partners, their view on finances, use of materials, planning, the role of administration, etc. I also opted for an all-female group from different generations, since female artists are still systemically underrepresented in the arts field.

Špela Petrič is a well-known name in the bio-arts and critical plant studies field and has been working with plants and plant governance for many years already. I wanted to collaborate with her around the ethical questions that working with plants has raised over all those years, how the actual physical reality of her vegetal collaborators influences her work both aesthetically and productionally, and how or if her collaborating with plants has changed her view on the human in contemporary society. Vinny Jones is a light artist, working with methodologies of sensory scenography. I invited her to extend her research on surveillance, sensory marketing, and how light and space can create subtle behavioural manipulations to the plant-human relationship. Through the interactions with biofeedback from the plants (taking into account the limitations of our technical equipment), we investigated notions of agency, control, care and manipulation. Sepideh Ardalani plays with herbs as ways for her to relate to the vegetal entities whose lives are entangled with ours. Within the context or Rooted Hauntology Lab she worked on how to let humans' sensorial experiences of specific plants speak for themselves, looking for possibilities of bypassing (spoken) language and how it assigns, limits, divides and categorizes these experiences. The invitation extended to Špela, Vinny and Sepideh was to explore what being-with plants could provoke in their artistic practices, and to make an invisible relation visible through co-working with plants. The aim was not to come up with clever new ways of making plant life or plant agency visible through an artwork, but, rather, to question ways of working and meeting audiences drawn from the realizations of our co-working with plants.

Within the residencies, being-with meant suspending the desire to come to conclusions or agreements about the problems raised. Being-with plants brings to light the difficulties of power relationships that are always at play both in artworks themselves as well as in collaborations. Approaching plants as ghosts and committing to making the invisible relationalities visible meant that we had to find ways to make the power relations we experienced an explicit part of the work. Within the residency, our relating to plants still mainly happened through the use of plants or the projection of human attributes onto them and their wellbeing, while the experiences of the plants themselves remained absent, unable to be voiced, let alone "understood". In Sepideh's practice of picking, drying, tincturing and ingesting plants, she looked for answers to this relation of unidirectional use. She writes in the program note of the séance:

\footnotetext{
In the case of phytofraction, the medicine lies in the imagination of vegetal transgression towards the human. When mutualising the agency to transgressmaybe the healing can be mutualised too. Re-channelling the healing capacity to not flow one-directionally from plant to human but to an interface between the vegetal and human. Maybe drinking an infusion of elder flowers can perform mutual healing? Maybe the potential for transgression acted out from the vegetal towards the human, could possibly help to imagine plant agency with plasticity? (Vranken et al. 2019)
} 
Similarly, Špela questions the relational framing between herself, the plants, and the audience:

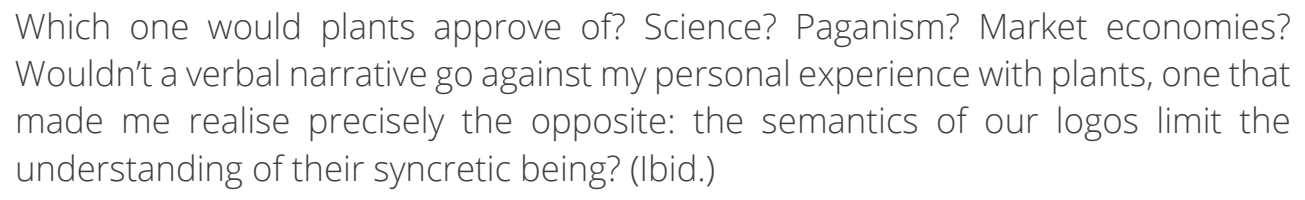

In Vinny's research, too, it is the human artist who makes choices and attributes values to the information she receives in the form of biofeedback, choosing which data is translated into a specific light or colour. She aims to equalize the hierarchies between humans and plants within her work by equally manipulating both, prompting her to state:

\section{It is a fascinating idea that light can be designed to elicit specific human responses, such as increased concentration, productivity or creativity. The optimising of these functions is now included in workplace light design, in public space and retail. Light is being used to promote specific behaviours and discourage others. It is not only plants that are being shaped in greenhouses. (Ibid.)}

Despite our best intentions of care, the option we are left with is maybe a cautious humility, rather than the certitude of claiming that our acts are caring rather than oppressing. Staying with the uncertainty of the effects of our actions is possibly a first step in shifting the power dynamics that lie between us and the plants and between all of us as collaborators.

The experiences and problems of the residency were opened up to an audience during a 14-hour long "séance" at Zone2Source, an art space focusing on the intersections of art, science and nature in Amstelpark, Amsterdam. The word "séance" hints both at the summoning of ghosts, as well as at the common meaning of the word in French: a session. The term was chosen to emphasize that this was not an event, nor a service or entertainment; it was not created to be consumed. A ghostly séance needs its participants' commitment and conviction, it demands you to be-with every entity in it, even if we don't know what will appear. A séance asks us to suspend any disbelief we might hold. It is playful serious business, creating a ghostly loophole in reality that has the potential to haunt on for a longer time. We extended the invitation to be-with to the audience through proposing different economies of attention: the audience was not presented with "finished" art works ready for consumption, but various ways of entering into dialogue with the research of the Lab and all the entities (present, absent, human, other-than-human) that had been part of that research, including the necessary invisible labour such as cleaning and making food. The notion of time was of great importance: the 14-hour timeline allowed us to stretch the conventional economy and experience of time within an artistic encounter. Presentations, which included sound pieces, lectures, performances, installations and participatory exercises, were either durational or spaced at least two hours apart, leaving ample space for the audience to exchange, take a nap, leaf through the library, make copies of texts or engage with the human and vegetal co-workers. This approach also created the kinds of tensions that come with being-with: some audience members were confused about "what was happening now" or "where the exhibition was." Audience 
members were invited to sign a commitment to be-with all entities present, offering people the space to attune to the multitude of things happening, that seemed invisible at first.

As the day went on, more and more audience members appeared to become co-hosts by making time for conversation with newly arriving guests, or by reading together. On a foraging walk in the park, everyone was invited to bring their knowledge of edible plants (or lack thereof). As we were walking through the park, enjoying the green surroundings and focusing in on the plants that would later become part of our collective dinner, we contemplated how our relationship with plants is not self-evident. The park had designated "wild spots" where nettles and wild garlic were "allowed" to take over, but these attempts at "wilderness" were in fact highly curated within the context of a manicured park built for the Floriade in 1972, the biggest international garden architecture exposition. Being in the midst of these plants, enjoying their presence and being attuned to them also made the act of eating into a more conscious confrontation with our day-today exchanges with the vegetal: plants are building us on the most basic level, through their deaths they are being transformed into us and we into them. In the act of eating itself, the binary opposition between the human and plant that seems almost unavoidable when using language starts to dissolve.

\section{Step 3}

We invoke the ghost Mugworth, Bijvoet, Puju!

Artemisia Vulgaris is considered a protector of woman and forest creatures. For people who farm or garden, they are an enemy since they survive any herbicide you spray at them. The oils of the plant are toxic when taken in, in large amounts over a long period of time. But in small dosages they are considered to assist with dreaming, imagining and visioning. Those who use Mugworth are said to be able to live in several worlds at once.

We invoke Mugworth to expand our gaze to past and future.

We invoke Mugworth to make the invisible visible.

We invoke Mugworth to help us stay with the trouble and live in complexity.

We invoke Mugworth to resist the tyranny of linear time and the constant now.

Take some Mugworth in your hands and warm them up by rubbing your hands together. The warmth will activate the chemicals inside Mugworth, so they become more volatile.

Now inhale the smell for 7 long breaths.

Put Mugworth in your bag and sweep your hands across your forehead to allow the left-over oils of the plants to seep through the skin, into our brains, where they can do their work. 
In terms of thinking about the curatorial position in general, I worked with the idea of vegetal generosity. Michael Marder proposes that plants are ontologically generous (Marder 2018, p.22). Generosity is how and what they are; in their act of growing they produce excess, the conditions for both themselves and other entities to thrive. In collaboration with micro-organisms and mycelium, plants have created the foundations for other life on earth to emerge; without plants, no oxygen rich atmosphere for mammals to breathe. I would like to imagine a vegetal generous mode of (performance) curating, producing excess and providing the conditions for both artists and audiences to thrive, to connect and exchange. A practice not only concerned with its own life forms, but making life possible for others-human and other-than-human alike. However, the desire for generosity also brings vulnerability. What can be a generous attitude in the face of possible exploitations? What kinds of generosity can we foster from situations of precarity?

This inspiration from the vegetal generosity translated itself towards the artists by first of all allocating $80 \%$ of the budget towards artist fees. Even though in this case we are talking about the very small production budget that was provided by the graduate school, this was symbolically of great importance since artists are often left unpaid. Secondly, generosity could be found in how time and attention were distributed during the residencies, while resisting extractivist and precarious practices of offering more time and energy than we could actually give. It became a matter of what we spent our time and attention on: being generous to the process and its questions rather than focusing and putting pressure on the "outcome." Through organizing feedback sessions for each other and sharing references and information, but also collectively sewing the curtains needed for Sepideh's installation.

Within the séance this generosity became an invitation to the audience to approach all elements present, visible and invisible, as a commons. This invitation was also woven into the details of hosting and in the overarching scenography of the space. There was a library consisting of all the books and texts that had made up the research. The various notes and mappings from the whole process were present for people to browse through and use. A copy machine and office supplies made it possible for people to make their own reader. Nothing of the process was hidden, all was offered up to become oxygen or humus. This open source approach was mirrored in the space which had no "backstage" or invisible organisational labour: the chairs, tables and cushions could be moved around by the audience to fit the needs of the different presentations taking place, and cleaning and care tasks were shared. In the program, generosity was present in the brief for the various lectures, making sure they were understandable to the different levels of knowledge and expertise present, and offering time for discussion and collective exercises that could translate the philosophical or scientific concepts presented into everyday life. Sepideh Ardalani was available for audience members to consult for more information on herb practices and the herbal drinks and herb-rooms she had set up. All of these curatorial choices were small gestures aimed at shifting habits of consumption into practices of commoning. The space, the time, the artworks, artists, plants, books, other audience members, etc. became something we collectively benefit from and care for. 
Donna Haraway describes sympoiesis as

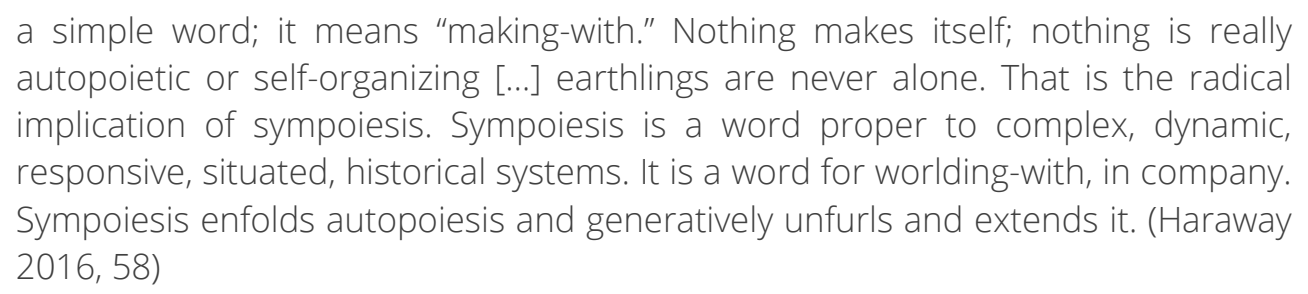

The invitation to co-work with plants in order to make an invisible relation visible is an attempt at a conscious and specific sympoiesis. Plants make our sympoietic reality, our becoming-with our environment visible and tangible. The plants' living form is a constant interpretation, evaluation and exploration of their surroundings (Marder 2016, 20). Within the residency process, the artistic researches and the séance we attempted to be as conscious and acknowledging as we could towards what was creating (with) us. Through the act of inviting the artists with a very specific question, the creation of a peer space in which the individual artistic practices could take place and the attention for sympoiesis, we could see a different possibility of authorship emerge between us that I would for now describe as a variety of distributed authorship (Ascott 2005, 282). Vinny worked on a light installation, operated by biofeedback from the vegetal co-workers that provided the light environment for the whole duration of the séance. The light frequencies we used varied between those seen as most beneficial for plant health and those considered most beneficial for human well-being. The light installation also communicated with the light coming from outside, since the Glass House in which Zone2Source is operating has three full glass walls opening out to the surrounding park. Sepideh proposed "herb rooms" inside and outside of the space, in which audience members were invited to encounter specific vegetal beings through the different senses of taste, touch, smell, sight. The audience was asked to contemplate the naming of the encounter through the information they got from these sensorial interactions. Špela proposed a meditative exercise followed by a lecture on Shoshana Zuboff's The Age of Surveillance Capitalism and guiding us to her conclusion and provocation that in the eyes of the algorithm, we are all plants. We, humans and other-than-humans alike are 'the vegetariat'-a new precariat: raw material to be mined by the algorithm, generously giving away this "excess" of data.

The invited artists proposed three distinct approaches to the question to make something invisible visible; Their autonomous artistic processes were made porous through consciously acknowledging the multiple influences which make a work, in this case in specific the vegetal coworkers and each other. This is something very different than a simple co-authorship or cocreation. Each of the invited artists came with their own autonomous artistic proposal, but their processes were opened up, influenced and contaminated by each other. They all testified afterwards that what they created within the context of Rooted Hauntology Lab was something very different than what they would make otherwise. The curatorial work, then, was not to weave these distinct artworks together into a single narrative, but rather the opposite: to create the 
conditions for works to emerge together and speak to each other through their rooting in a common soil. This distributed authorship was further emphasized by mentioning our distinct vegetal co-workers in the credits, as well as writers who have been significant to the project. The presence of the library made the influences and research of the project visible and accessible to all. Also, the audience was encouraged to become an author of the séance, by leaving traces in the space, adding questions and making proposals.

On a more subtle level, the dramaturgy and rhythm of the whole séance was based on the positioning of the sun. In reality the séance had already started the evening before, through the means of a lecture performance sharing a recipe for vegetal infiltration with the audience. By starting off the séance in the late evening before, the night and time of dreams were taken along into the dramaturgy of the whole. The timing of the different interventions was made with the specific location of the sun during the day and the energy it gives or takes in mind. The séance wanted to be more than the sum of its parts; it aimed to be a temporary ecosystem where the different curatorial, artistic and social elements were clearly distinguishable but their relations to each other were also clear and celebrated. Through all of these subtle interventions and experimental practices the séance proposed the audience encounter as an opportunity to create together, to create with those who are recognized as present and with the ghosts. Invisible to the audience, a different kind of writing together was happening on the administrative level. In an attempt to be conscious about relationality within all the aspects of how we were organizing ourselves (and were being organized by what surrounded us of course!) we attempted to make contracts that could describe all of our relations and (temporary) agreements within the process, rather than the contract being a dry description of a financial transaction. Where a normal residency or coproduction contract focuses on the financial and legal obligations towards each other, we started to compile the different human needs and desires that we held for our collaboration, as well as the unsolved issues and the ideas that we did not manage to develop. The contract was continuously adapted and became a trace of the collaboration itself.

Rooted Hauntology Lab, as an ongoing project, is a cautious and humble attempt at rehearsing different ways of relating in a time and place where relating can no longer be claimed as innocent. Rooted Hauntology Lab is bound to fail. These first experiments have also pointed out the blind spots, such as the difficulty to find alternatives to the anthropomorphising of other-than-humans and the lack of ways to deal with the power relations in which we are entangled. Time and time again we would notice there was use of human and other-than-human resources without the certainty of consent, there were expectations placed on each other, there was not enough money or time, there were audience members who might have needed more information or more food, there were plants who died, roots that rotted, soil that dried out, bugs that were squashed, Facebook that was used, a plane that was taken, an intern who was put under pressure. Thinking ourselves, our work, our responsibilities through all the relations is overwhelming and confronting. There is no easy way of navigating the haunted world we find ourselves in. But we may create spaces to exercise our attention to ghostly relations; we may exercise what it means to act on them and to shift how we live and work. For this we may find allies in the vegetal world. 
We invoke the ghost Daisy, Marjetica, Gänseblümchen!

Bellis Perennis is a well know garden guest of springtime. Historically, Daisy has been commonly known in English as Bruisewort and occasionally Woundwort, revealing that they can help with bruises and close wounds. Timetravel and future prehearsal is not without its dangers.

We invoke Daisy to teach us to cultivate softness, and receive softness as well. We invoke Daisy to teach us the continuing possibility for joy, even in uncertainty.

Take Daisy and stroke them across your face-very gently. Give them the softness of your skin, and receive the softness of their petals in turn.

When you feel you are ready, add Daisy to your bag.

Close your bag tightly.

Press it against your right temple.

Put it in your agenda or in your laptop bag. Somewhere where you will find them, the next time you enter an institution or you start your work.

Take the time to get to know these vegetal ghosts, know that you have the potential to make space for them, open the door for them to infiltrate, to take over. Allow yourself to be influenced by their potential for change and the creation of other timescales and practices.

\section{Works Cited}

Acosta, Alberto. 2013. "Extractivism and Neo-extractivism: two sides of the same curse." In Beyond Development: Alternative Visions from Latin America. Edited by Miriam Lang and Dunia Mokrani, 61-86. Amsterdam: Transnational Institute.

Ascott, Roy. 2005. "Distance Makes the Art Grow Further: Distributed Authorship and Telematic Textuality in La Plissure Du Texte." In At a Distance: Precursors to Art and Activism on the Internet. Annmarie Chandler and Norie Neumark, 282-297. Cambridge, MA: MIT Press.

Bieman, Ursula, and Paulo Tavarres. 2014. Forest Law: Selva Jurídica. Lansing, MI: Eli and Edythe Broad Art Museum, Michigan State University.

De Meyer, Silvie. 2017. Sensor Rapport: Resultaten van de sensor binnen de sector podiumkunsten en muziek. Gent: Attentia \& Sociaal Fonds Podiumkunsten.

Dempster, Beth. 1995. System Stability and Implications for Sustainability. B.Sc. Thesis, University of British Columbia. Derrida, Jacques. 1994. Spectres of Marx. Translated by Peggy Kamuf. New York and London. Routledge.

Fisher, Mark. 2014. Ghosts of My Life: Writings on depression, hauntology and lost futures. Winchester: Zero Books. Hallowell, Irving A. 1960. Ojibwa Ontology, Behavior, and World View. New York: Columbia University Press. 
Haraway, Donna J. 2016. Staying with the Trouble: Making kin in the Chthulucene. Durham, NC: Duke University Press. https://doi.org/10.1215/9780822373780

Kuzmanovic, Maja, and Nik Gaffney. 2018. "Terrafictions."

https://medium.com/aperiodic-mesmerism/terrafictions-109274bf8336

Marder, Michael, and Anaïs Tondeur. 2016. The Chernobyl Herbarium: Fragments of an Exploded Consciousness. London. Open Humanities Press. https://doi.org/10.26530/OAPEN_606220

Marder, Michael. 2018. "Musings on Vegetality." In Botanical Speculations. Edited by Giovanni Aloi, 19-28. Cambridge: Cambridge Scholars Publishing.

Schiebinger, Londa. 2007. Plants and Empire: Colonial Bioprospecting in the Atlantic World. Cambridge, MA: Harvard University Press.

Simard, Suzanne, Kathy Martin, Alan Vysem, and Bruce Larson. 2013. "Meta-networks of fungi, fauna and flora as agents of complex adaptive systems." In Managing World Forests as Complex Adaptive Systems: Building Resilience to the Challenge of Global Change. Edited by Christian Messier, Klaus J. Puettmann, and K. David Coates, 133-164. New York: Routledge.

Simard, Suzanne. 2018. "Mycorrhizal networks facilitate tree communication, learning and memory." In Memory and Learning in Plants. Edited by Frantisek Baluska, Monica Gagliano, and Guenther Witzany, 191-213. Cham: Springer. https://doi.org/10.1007/978-3-319-75596-0_10

Szymborska, Wisława. 1999. "The Silence of Plants." Poems New and Collected. Translated by S. Baranczak and C. C. Cavanagh. London: Faber \& Faber.

Tsing, Anna, Heather Swanson, Elaine Gan, and Nils Bubandt, eds. 2017. Arts of Living on a Damaged Planet. 2 vols. Minneapolis: University of Minnesota Press.

Vranken, Ingrid, Špela Petrič, Vinny Jones, Sepideh Ardelani, Maja Kuzmanovic, and Nik Gaffney. 2019. Program note, Rooted Hauntology Lab séance \#1 (unpublished).

Wandersee, James, and Elisabeth Schussler. 2001. "Toward a Theory of Plant Blindness." Plant Science Bulletin 47 (1). https://www.botany.org/bsa/psb/2001/psb47-1.html\#Toward\%20a\%20Theory\%20of\%20Plant

Wenner, Stefanie. 2019. "Bürgerliche Dämmerung." Program note, Rooted Hauntology Lab séance \#1 (unpublished).

Wohlleben, Peter. 2015. The Hidden Life of Trees. London: Harper Collins.

\section{Rooted Hauntology Lab - credits}

Rooted Hauntology Lab / Séance \#1 is Vinny Jones, Sepideh Ardelani, Špela Petrič, Bryana Fritz, Ingrid Vranken, Evelien Geerts, Maja Kuzmanovic, Nik Gaffney, leva Pranckunaite, Saracenia, Monstera, Mimosa, Nettle, Mugwort, Money tree, Aloë Vera, Calathea, Blue fern, Lepelplant.

Advised by Stefanie Wenner and Arthur Kneepkens

With special thanks to Lara Staal, Rasa Alksnyte, Kate Rich, Gaëtan Dartevelle, Suzanne Knip-Mooij, Silvia Botirolli, Barbara Van Lindt, all my peers at DAStheatre, Alice Smits, Zone2Source, FoAM.

Inspired by the texts by Donna Haraway, Rosi Braidotti, Sara Ahmed, Karen Barad, Vandana Shiva, Mark Fisher, Michael Marder, Anna Tsing, Achille Mbembe, Giovanni Aloi, Jane Bennet, Bojana Kunst, Silvia Federici, Deleuze \& Guattari, Isabelle Stengers, Karen Bek-Petersen, Maggie Nelson, Michel Serres, Nicole Krauss, Peter Wohlleben, Rebecca Solnit, T.J. Demos, Tavarres \& Bieman, Thijs Lijster, Alberto Acosta, Walter Benjamin and countless conversations, articles, tips, by many other critters 


\section{Biography}

Ingrid Vranken completed an MA in Theatre Studies at the University of Antwerp and Freie Universität Berlin as well as a Master in the Arts at DAStheatre in Amsterdam. She works as a dramaturg, producer and curator for multiple artists and arts organizations in Flanders. (a.o. SPIN, David Weber Krebs, Walter Verdin, Maria Lucia Cruz, Rosa Omarsdottir, Luce Goutelle, Helena Dietrich, Bâtard Festival). She is a member of FoAm, a transdisciplinary laboratory at the interstices of art, science, nature and everyday life. Her work focuses on connecting the arts and ecology, not only as a theme of artistic work, but also as a way to transform artistic processes and practices. Her research focusses on new collaborative, curatorial and dramaturgical models, and a wider ecological and postcapitalist transition, that include other-than-humans.

(c) 2020 Ingrid Vranken

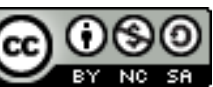

Except where otherwise noted, this work is licensed under a Creative Commons AttributionNonCommercial-ShareAlike 4.0 International License. 